\title{
United Nations Security Councils' Response to the Darfur Conflict in the Sudan: An Appraisal
}

\author{
Tambe Endoh Fabrice
}

\author{
Faculty of Law, University of Fort Hare \\ PB X1314, Alice 5700, South Africa \\ Email: fablosa88@yahoo.com
}

Doi:10.5901/mjss.2014.v5n4p604

\begin{abstract}
The Darfur conflict that erupted in 2003 triggered a global debate among scholars as to whether or not the United Nations Organization (UN) has been effective in the resolution of conflicts in Africa. From the on-set of the conflict, the UN Security Council voted for a series of resolutions including resolution 1593 to refer the Darfur case file to the International Criminal Court (ICC) for proper clarification on the crimes committed against the Darfur victims. Even though the case was brought before the ICC, human rights violations still continued in the region. The Security Council further engaged in the adoption of resolution 1706 to promote the deployment of military troops for the restoration of peace in Darfur. Despite this commitment, recent findings reveal that, the Council's efforts have proved to be less successful as the crisis is still sustained. This paper samples some of the resolutions and the views of other scholars on the efficacy of the UN operations in Darfur and the entire region of Africa. In conclusion, the author argues that the UN has not and continues not to be effective in resolving the crisis in Darfur. He proposed restructuring the UN Security Council to meet the needs and interest of the global community.
\end{abstract}

Keywords: Conflict, Security Council, Resolutions, United Nations response, Darfur-Sudan

\section{Introduction}

\subsection{Brief history of the Darfur situation}

Darfur is located in the western part of the Sudan with a population of about 5.6 million people who are predominantly Muslims, distributed among five ethnic zones which are North Darfur, South Darfur, West Darfur, Eastern Darfur and Central Darfur (Darfur population census, 2013). The most populated area in Darfur is inhabited by non-Arabs in the Western part. (Robert 2006, p.9) The Southern part is occupied by cattle and camel nomads who are practically of Arab origin and speak Arabic. The Northern part serves as a home for camel nomads who are also affiliated to the Arab clan. Ethnic clashes over scares resources like water and grazing land in Darfur resulted to a full blown conflict in February 2003 when the Sudan Liberation Army (SLA) attacked and attempt to capture the town of Gulu. Another attack launched in March to recapture Gulu resulted in a fierce fight that killed one hundred and ninety five government soldiers (Robert, 2006). From the on-set of the conflict, at least 400,000 people have been reportedly killed and more than 2.5 million civilians displaced (Omer, 2008. p.4). The displaced persons now wonder in deep frustration in displaced persons camps in Sudan and refugee camps in neighbouring Chad. The conflict is calculated to have left more than 3.5 million people completely reliant on international aid for survival.

\subsection{United Nations mandate to restore peace in Darfur}

Close to a decade, human rights and humanitarian organizations have been calling on the international community to fulfil its responsibility to protect the victims of brutal killings, rape and other atrocities committed in the Darfur region of Sudan (Colum, 2009). The UN being the principal body tasked with the responsibility of maintaining international peace and security responded to this call by employing certain measures in conformity with its mandate and international law. The UN organ vested with the mandate for maintaining international peace and security is the Security Council (UN Charter, Art. 24). The Charter of the UN spells out clearly that member states of the UN have agreed that in carrying out its responsibilities, the Security Council acts on their behalf (UN Charter, Art. 1(2)).

In the case of a conflict of an internal or international nature, Article 41 of the UN Charter empowers the Security Council to take necessary measures not involving the use of armed force, in order to maintain peace and stability (UN 
Charter, Art. 1(2)). For such measures to be taken, Article 39 of the Charter provides that, there must have been a threat to the peace, breach of the peace or act of aggression. Where such measures provided for in Article 41 are, or prove to be inadequate, the Security Council may take further actions as stipulated under Article 42 of the Charter to remedy the situation. Acting under Chapter VII of the UN Charter, the Security Council has adopted a series of resolutions to address the Darfur situation since the outbreak of the conflict in 2003. It is therefore important to find out if these resolutions have had any effect in ameliorating the situation in Darfur.

\section{United Nation Security Council's Response to the Darfur Conflict}

The UN Charter prohibits the use of force and spells out explicitly the circumstances under which it can be used. In this regard, the role of the Security Council becomes of paramount importance. The International Commission on Intervention and State Sovereignty reported that the Security Council is the only organ competent to authorise interventions with respect to conflicts around the world (Report of the International Commission on Intervention and State sovereignty, 2001). Among others, the Darfur conflict has been dealt with by the Security Council through a series of resolutions discussed below. For the purpose of this paper, the focus will be on the main resolutions that aimed to restore peace and stability in the Darfur region. However, other resolutions adopted for the purpose of extending the mandate of peace operators will also be mentioned in order to have a balanced over-view of the general situation.

\subsection{United Nation Security Council Resolution 1556}

In its 5015th meeting, the UN Security Council adopted resolution 1556 by 13 votes in favor and non against, with 2 abstention (China and Pakistan). The Council demanded that the Government of Sudan disarm the janjaweed militia, apprehend and bring to justice its leaders and their associates who had incited and carried out violations of human rights and international humanitarian law, as well as other atrocities in the Darfur region (UN Security Council Resolution 1556, 2004). The government backed Janjaweed militias are said to have derived from the Abala camel-herding nomads who migrated to Darfur from Chad and West Africa in the 1970s, and from Arab camel-herding tribes from north Darfur. The Janjaweed have established a tradition called the Hambati or 'social bandits' taken from among the Arab tribes. They are robbers and vagabonds rejected by their communities for breaching established traditions (Donovan, 2005. p.7).

Other members of the Janjaweed are thought to be more professional criminals, including some allegedly released from prisons to join or lead the militia. (Donovan $\mathrm{P}, 2005$ ) The International Commission of Inquiry on Darfur describes the Janjaweed in the Arabic context as "devils on horseback" (Reeves, 2005. para.100). Building on the existing ethnic tensions, the government specifically armed the militia to bolster its military capability and turn a blind eye to the alleged reported looting and raping perpetrated against the Darfur indigenes (Donovan, 2005. p.7).

The Council pressed on the disarmament of the Janjaweed militia and further requested the Secretary General to report back in 30 days on the progress made (UN Security Council Resolution 1556, 2004. para.7) Resolution 1556 also called on the government of Sudan to fulfill immediately all the commitments made in the joint communiqué issued by itself and the Secretary-General on $3^{\text {rd }}$ of July 2004 , including particularly, and in cooperation with the UN, advancing the independent investigation of violations of human rights and international humanitarian law, establish credible security conditions for the protection of civilian population and humanitarian actors, and resume political talks with dissident groups from Darfur, specifically the Justice and Equity Movement (JEM) and Sudan's People Liberation Movement (SPLM) (UN Security Council Resolution 1556, 2004. para.1).

Adopting resolution 1556, the Council received little attention and lack of commitment from government authorities and also, Security Council members shared different opinions on the issue of imposing sanctions against the Sudanese Government. Some, important reasons for the adoption of resolution 1556 were the fact that Washington wanted to impose an oil embargo on the Sudan which would prevent it from selling its oil (Zygar, 2004). Although Secretary of State, Mr. Powell, immediately took the issue to the UN, it has since emerged that Washington's determination was by no means shared by all of the UN Security Council members. Whereas the US was willing to impose sanctions against Sudan, the United Kingdom and Australia even raised the possibility of armed intervention, but Russia, China and Pakistan staunchly opposed any actions against Sudan (Zygar, 2004). This lost opportunity might have led to humanitarian intervention, putting pressure on the Sudanese Government to end the devastation taking place in Darfur. Because of these diverse opinions between members, the Security Council had to establish an independent commission to investigate the issue of genocide in Darfur. 


\subsection{United Nation Security Council Resolution 1564}

In adopting resolution 1564, the Security Council expressed dissatisfaction and concern that the Government of Sudan had not fully met its obligations to protect civilians in Darfur. It declared that should Sudan fail to comply fully with resolution 1556 as stated above or cooperate with the expansion and extension of the African Union monitoring presence in Darfur, it would consider taking additional measures, including sanctions against the Sudanese Government (UN Security Council Resolution 1564, 2004. para.1). The Council also requested the Secretary-General to establish an international commission of inquiry which would immediately investigate reports of human rights violations in Darfur and determine whether acts of genocide had occurred there. The resolution was actually adopted by a vote of 11 in favour, none against, with four abstentions (Algeria, China, Pakistan and Russian Federation).

Although the Council paid attention in finding a solution to the crisis in Darfur, the conflict continues to rage on. The Council further adopted Resolution 1590 to establish for an initial period of six months, the United Nations Mission in Sudan (UNMIS). The latter consisted of up to 10,000 military personnel and an appropriate civilian component, including up to 715 civilian police personnel (UN Security Council Resolution 1590, 2005. para.1).

The Council decided, among others, that the mandate of UNMIS will support the implementation of the Comprehensive Peace Agreement (CPA) signed by the Government and rebel forces. The Mission was also tasked with facilitating the voluntary return of refugees and displaced persons, providing demining assistance, and contributing towards international efforts to protect and promote human rights in the Sudan. The Council also decided that UNMIS will be delegated the authority to take the necessary action in the areas of deployment of its forces to protect United Nations personnel, ensuring their security and freedom of movement, protecting civilians under imminent threat of physical violence.

\subsection{United Nation Security Council resolution 1591}

The Council continued its journey towards peace by adopting resolution 1591 to establish a committee to monitor sanctions imposed on Sudan, including travel bans, assets freezes and ban on weapons (UN Security Council Resolution 1591, 2005. para.3). It request the Secretary-General, in consultation with the Committee, to appoint for a period of six months, within 30 days of adoption of the resolution, a Panel of three Experts (PE) based in Ethiopia which will travel regularly to El-Fasher and other locations in Sudan, and operate under the direction of the Committee. By the terms of the resolution, the Council strongly deplored the failure of the Government of Sudan, rebel forces and all other armed groups in Darfur to comply fully with their commitments and the demands of the Council referred to in its previous resolutions (UN Security Council Resolution 1591, 2005. para.1).

The Council reiterates that in the event that the parties failed to fulfil their commitments and demands as outlined in the terms of the Resolution, and the situation in Darfur continues to deteriorate, it would consider further measures as provided for in Article 41 of the Charter of the United Nations. Awaiting a positive response from parties to the conflict, the Council further decided to remain seized of the matter (UN Security Council Resolution 1591, 2005. para.9).

\subsection{United Nation Security Council Resolution 1593}

Due to lack of full compliance on previous resolutions by parties on the Darfur conflict, the Council voted for resolution 1593 to refer the situation to the International Criminal Court (ICC) for proper clarification of the crimes committed in the region. The resolution was adopted by 11 votes in favour, non against and 4 abstentions (Algeria, Brazil, China, and United States) (UN Security Council Resolution 1593, 2005. para.1). By resolution 1593, the Council decided also that the Government of the Sudan and all other parties to the conflict in Darfur would cooperate fully with the Court and the Prosecutor, providing the Court with any necessary assistance (Statement by Security Council Representative, 2005). The Council Invited the Court and the African Union (AU) to discuss practical arrangements that would facilitate the work of the Prosecutor and of the Court, including the possibility of conducting proceedings in the region, which would contribute to regional efforts in the fight against impunity (UN Security Council Resolution 1593, 2005. para.3).

After referring the Darfur situation to the ICC the Council voted for resolution 1672 to impose travel restrictions and financial sanctions against four Sudanese individual's detailed in resolution 1591. The Council decided, among other things, that all States should take the necessary measures to prevent the entry into or transit through their territories of all persons designated by a Committee established under the resolution (UN Security Council Resolution 1672, 2006. para.3). In endorsing the decision of the African Union Peace and Security Council on the need for concrete steps to 
effect the transition in Darfur from the African Union Mission in the Sudan (AMIS) to a United Nations operation, the Security Council called for the deployment of a joint African Union and United Nations technical assessment mission in Sudan by unanimously adopting resolution 1679 on 16 May 2006 (UN Security Council Resolution 1579, 2006). It is worth noting that the government also signed an accord in May with factions of the Sudan Liberation Army (SLA) calling for the disarmament of the Janjaweed militias, and for the rebel forces to disband and to be incorporated into the army (Aljazeera.Net, 2006). However, the agreement was rejected by two other smaller groups, the JEM and a rival faction of the SLA (Kessler et al, 2006).

\subsection{United Nation Security Council Resolution 1706}

The Council adopted resolution 1706 on $31^{\text {st }}$ August 2006 to expand the mandate of UNMIS, and to include its deployment to Darfur in order to support the early and effective implementation of the Darfur Peace Agreement (DPA) (UN Security Council Resolution 1706, 2006. para.1). The resolution was adopted by 12 votes in favour and none against, with 3 abstentions (China, Qatar, and the Russian Federation). The Council invited the consent of the Sudanese Government of National Unity for that deployment, and called on Member States to ensure an expeditious deployment. It requested the Secretary-General of the UN to arrange the rapid deployment of additional capabilities to enable UNMIS to deploy in Darfur. Acting under Chapter VII of the UN Charter the Council authorized UNMIS to use all necessary means as it deemed fit in accordance with the Charter to deal with the situation in Darfur (UN Security Council Resolution 1706. para.12).

The Council extended the mandate of the UNMIS until 31 October 2007 by unanimously adopting resolution 1755 which requested the Secretary-General to urgently appoint a new Special Representative for The Sudan. (UN Security Council Resolution 1755, 2007. para.1) It also called on the parties to the CPA to accelerate progress on implementing all their commitments, in particular, to carry out the establishment of Joint Integrated Units and other aspects of the security sector reforms. The Council Called upon the parties to the CPA, the DPA, the N'Djamena Humanitarian Ceasefire Agreement, the Eastern Sudan Peace Agreement and the communiqué of 28 March 2007 to respect their commitments and implement fully all aspects of those agreements without delay (UN Security Council Resolution 1755, 2007. para.4). In addition, it called on those parties that had not signed the DPA to do so without delay and not to act in any way that would impede its implementation (UN Security Council Resolution 1755, 2007).

\subsection{United Nation Security Council Resolution 1769}

In furtherance of positive steps to quell the violence in Darfur, the Security Council unanimously voted in resolution 1769 to authorize the deployment of a 26,000-strong joint force of United Nations-African Mission in Darfur (UNAMID) (UN Security Council Resolution 1769, 2007). Under this resolution, the 15-member body would have up to 19,555 military personnel, including 360 military observers and liaison officers; a civilian component of up to 3,772, international police; and 19 special police units with up to 2,660 officers. (UN Security Council Resolution 1769, 2007. para.2) Acting under Chapter VII of the UN Charter, the Council authorized UNAMID to take the necessary action to support the implementation of the DPA, as well as to protect its personnel and civilians "without prejudice to the responsibility of the Government of Sudan" (UN Security Council Resolution 1769, 2007. para.3).

Members of the Security Council welcomed the resolution, warning that it was only the first step in an arduous process, the ultimate goal of which was ending the suffering in Darfur and securing a lasting peace (UN Security Council Resolution 1769, 2007. para.9). Most speakers also enjoined the parties, particularly the Government of Sudan, to cooperate fully with the deployment and to pursue a sincere path to a negotiated peace.

In February 2010, the Sudanese government and the JEM signed a ceasefire agreement with a tentative agreement to pursue further peace. Based on the talks, the JEM hoped to gain most, including semi-autonomy, compared to South Sudan at that time (BBC News, 23 February 2010). However, talks between the two parties became fragile by accusations that the Sudanese army resumed air strike raids against a village, violating the February agreement (BBC News, 4 May 2010). Following the accusations levied against the government, the JEM promised to boycott further negotiations keeping the peace process unstable (BBC News, 4 May 2010).

So far the Darfur conflict has defiled resolution and the Councils' efforts towards achieving a stable peace in the region have been counter-productive. It is therefore not enough for the Council to rely solely on the previously adopted resolutions. Much still needs to be done since the violence is still on-going. There is need for a stronger military operation to counter the challenges posed by the different rebel factions and the Janjaweed militia. In performing this task, the 
Council needs to be united and more authoritative in making decisions that affect the peace process. The authority to make such decisions happens to be a primary right contained in the Charter of the UN and as such, it is the legal duty of the council to utilise such a delegated authority.

\section{An Appraisal of the Security Council's Response to the Crisis in Darfur}

Despite the arms embargo imposed on Sudan by resolution 1556, resolution 1769 re-iterated that continuous attacks on civilians, wide spread violence and sexual abuses were still going on in Darfur (UN Security Council Resolution 1769, 2007. para.13). The Council emphasized the need to bring to justice the perpetrators of such crimes and urged the Government of Sudan to do so. Because of the Sudanese Government ineffective response, the Council further adopted resolution 1841 on the $15^{\text {th }}$ of October 2008 to extend the mandate of the arms embargo. (UN Security Council Resolution 1841,2008$)$ Notwithstanding these measures, recent reports still give a negative picture about the situation on the ground (Annette, 2012).

Radio Dabanga, the only media outlet that routinely provides uncensored information from Darfur in recent months painted a disturbing picture of reports of civilians fleeing the government's aerial bombardments in the Jebel Marra area. (Rebecca H, 2010) It was masked by the massacre of at least 49 civilians at a market in Tabra, North Darfur; government restriction of aid agencies; access to Kalma, one of the largest displacement camps in Darfur; government obstruction of United Nation Children's Fund (UNICEF) reporting on child malnutrition rates in Darfur; and continuing sexual violence and fatal clashes among Arab fighters (Rebecca, 2010). Rebecca's findings also reveals that the Sudanese government routinely deny foreign journalists access to the conflict-ridden region of Darfur, and Sudan-based media are subject to government censorship (Rebecca, 2010).

Resolution 1935 (2010) extended the mandate of UNAMID until 31 July 2011 with an authorized military strength of plus 19,555 police and civilian personnel (UN Security Council Resolution 1935, 2010. para.1). It also requested UNAMID to develop, with the United Nations country team, a strategy to fully achieve its objective of protecting civilians and ensuring access to them by humanitarian workers (UN Security Council Resolution 1935, 2010. para.4). It stressed the importance of setting realistic targets against which the mission's progress could be measured. The Council urged all parties involved in the conflict to comply with their obligations under human rights and international humanitarian law, and to commit them-selves to a sustained and permanent ceasefire (UN Security Council Resolution 1935, 2010. para.8).

The Council also urged all parties, including all rebel factions, to engage fully in the on-going peace talks under the African Union-United Nations Joint Chief Mediator, with a view of reaching a comprehensive agreement that would bring a durable peace to the region. It reaffirmed the importance of promoting the political process for Darfur, led by the African Union and the United Nations. This underlined the need for systematic and sustained engagement by all Darfur stakeholders in creating an environment conducive to peace and security "through constructive and open dialogue" (UN Security Council Resolution 1935, 2010. para.5).

In responding to the Council's plea, leaders of the rebel movements issued a joint statement on January 292011 affirming their commitment to the Doha negotiation. The Sudanese government failed to attend the session, but later agreed to return to the Doha peace forum with a view to completing a new peace agreement by the end of the month (Sudan Tribune, 2011). However, on February 25 2011, the leaders of the rebel movements announced that they rejected the peace document proposed by the mediators in Doha (Sudan Tribune, 2011). One of the rebel leaders, Ahmed Hussein Adam, mentioned beforehand that the peace process in Doha has been turned to a tribune for political manipulations in a way that presents President Omar Al Bashir as a peace lover seeking to resolve the Darfur conflict peacefully (Sudan Tribune, 2010). He argued that despite Khartoum's manipulative tactics, she did not desist from the military option and also did not want to deal with the root causes of the conflict. Rather, she simply sought to absorb the rebels within the regime of the National Congress Party (Sudan Tribune, 2010).

The Doha Peace plan was said to have been undermined by the AU partly because of the issues rose above (Sudan Tribune, 2010). The plan was therefore stalled until July 2011 when the government came to a mutual understanding with the rebels. The Doha Agreement was finally signed on July 14 between the government of Sudan and the leaders of the SLM and JEM (Sudan Tribune, 2011). Although the agreement went through successfully, the JEM expressed reservation about the implementation of the peace plan.

Despite the Doha peace agreement, recent findings shows that attacks and killing of civilians in Darfur is still widespread. UNAMID reported that on April 20 (2012) a team of 32 officers had been on a routine patrol just before midday near Sisi displaced camp when they were attacked by men armed with AK-47 rifles (Sudan Tribune, 2012). The group was returning to their base in Mourne, which is about 70 kilometres southeast of El Geneina. The attack came as 
local officials said that on April 18 2012, Darfur rebels killed 11 soldiers from the Central African Republic (CAR) on the Sudanese side of the international border, who were part of a three way Chad-Sudan-CAR border force (Sudan Tribune, 2012).

From the above analysis, there is an indication that the Security Council lacks a defined mechanism to properly handle the issue of human rights violations in Darfur as the violence is still on-going. In its previous resolution 1769, the Council had recognised that if good policies and proper targeting mechanisms are not put in place, the on-going violence in Darfur might further affect the rest of Sudan (UN Security Council Resolution 1769, 2007. para.16). Cedric confirms that the fighting in the Darfur region has affected the entire Republic of the Sudan, making it very unstable and difficult to govern as a state (Cedric, 2011).

The conflict in Darfur is still sustained since a permanent solution has not been found by the Security Council. Arms restrictions have not been complied with as the violence is still going on; a cease fire agreement failed; and a DPA has not been reached. With the prevailing situation, one can conclude that the response of the Security Council has not been effective as far as Darfur is concerned. As such, the Council is still searching for resolutions that would bring peace to Darfur. Of the most recent is resolution 2035 of 17 February 2012 that extends until 17 February 2013 the mandate of the Panel of Experts, originally appointed pursuant to resolution 1591; it requests the Secretary-General to take the necessary administrative measures, including basing arrangements, as expeditiously as possible. By unanimously adopting resolution 2035, the Council acknowledged the creation of two additional states in Darfur on 11 January 2012, and confirmed that all previous references to North, South and West Darfur shall apply to all the territory of Darfur, including the new states of Eastern and Central Darfur (UN Security Council Resolution 2035). It required the Panel of Experts to provide monthly updates to the Committee regarding its activities, including obstacles encountered to the fulfilment of its mandate, as well as violations of the sanctions (UN Security Council Resolution 2035, 2012. para.6).

The Council reiterated that some individuals affiliated with the Government of Sudan and armed groups in Darfur have continued to commit violence against civilians. In this regard, it requested the Panel of Experts to coordinate its activities as appropriate with the operations of the UNAMID and with international efforts to promote the political process in Darfur (UN Security Council Resolution 2035, 2012. para.8). This process will also be helpful in its interim and final progress reports towards reducing violations by all parties of the measures imposed by resolution 1556 and resolution 1591. It will also accelerate progress towards removing impediments to the political process, threats to stability in Darfur and the region, violations of international humanitarian and human rights law and other atrocities. Some of these atrocities include sexual and gender-based violence and other violations of the above-mentioned resolutions, providing the Committee with information on the individuals and entities that meet the listing criteria in paragraph 3 (c) of resolution 1591.

Paragraph 3(c) of resolution 1591 provides that those individuals, as designated by the Committee established by subparagraph (a) of the latter, and based on the information provided by Member States, are those who impede the peace process in Darfur. By means of their actions, they constitute a threat to stability in Darfur and the region. They also commit violations of international humanitarian and human rights law including other atrocities that violate the measures implemented by Member States in resolution 1556 (2004).

The Council requested the Panel of Experts to continue to investigate the role of armed, military, and political groups in attacks against UNAMID personnel in Darfur. In the view of the Council, individuals and entities who plan, sponsor or participate in such attacks constitute a threat to stability in Darfur and may therefore meet the designation criteria provided for in paragraph 3 (c) of resolution 1591 (UN Security Council Resolution 1591, 2005).

However, the effectiveness of the Council's operation in Darfur remains questionable. The voting pattern adopted by Council members in some of the previous resolutions was not uniform. Furthermore, most of the resolutions were not voted for unanimously. A good example is resolution 1593 which referred the Darfur situation to the ICC (Statement by Security Council Representatives, 2005. para.2). The resolution was adopted by 11 votes in favour, non against, with 4 abstentions (Algeria, Brazil, China, and United States). At a time when the Council was seeking for a legal solution to the Darfur conflict, some of its members, including those vested with the veto power acted in a manner that undermined the credibility of its authority. The Council otherwise acted as an opposition to its decision and by way of inference, this division as reflected in the voting pattern proves that voting in the Security Council is informed and driven by self-interest and not necessarily by the need to resolve the conflict.

\section{Scholarly Perspective of UNs' Operations in Darfur and Other Parts of Africa}

Smith and Jowell state that a discretionary authority must in general be exercised only by the authority to which it has 
been delegated (Tolstoy, 1973. p.134). It is a well-known principle of law that when a power has been confided to a person in circumstances indicating that trust is being placed in his/her individual judgement and discretion, he/she must exercise that power. If he/she has been expressly empowered to delegate it to another, he/she cannot act otherwise. This applies to the delegation of all classes of powers, including the Security Council's power to decide on issues of conflict.

In the Lockerbie case, Judge Shahabuddeen comments that the question raised by Libya on the validity of the Security Council resolution 748 was whether a decision of the Security Council overrides the legal interest of states (Tolstoy, 1973. p.134). If so, whether there are any limitations of the powers of the Council to characterise a situation as one, justifying taking a decision entailing such consequences. Are there any limits to the Council's power of appreciation in disputes concerning members of the UN? If there are any limits, what are those limits and what body other than the Security Council, is competent to say what those limits are?

In the critical words of Professor Richard Falk and in response to Libya's challenge, "there is lack of consistency in practice". Failure to articulate principal lines when a UN response is inappropriate and reliance on unrestricted mandate to coalition of states led by the United State (US) makes the Security Council to be perceived as an instrument for geopolitical initiative currently dominated by the US (Tolstoy, 1973. p.134).

Former South African President, Thabo Mbeki lamented that Africans had lost faith in the world governing body (Sunday Times, 2011). Western control over the UN has capacity to lead to powerful nations installing leaders they preferred and to running the continent. There is weakened confidence of the Africans in this body. The task of UN peacekeepers in the Côte d'Ivoire was to maintain peace between the North, occupied by the rebels and the South by government. The UN was supposed to make sure that the peace agreement is signed, that the two sides don't clash and find a political solution. But what did the UN do? It opened the door for the rebels in the North to march into Abidjan and carry out operations there side-by-side with the UN forces. These are neutral peace keepers but they took sides. In Libya, the UN delegated its authority to the North Atlantic Treaty Organisation (NATO), a military formation of some countries, not a global body accountable to the UN. We have UN acting in a manner which is promoting particular agendas.

Mbeki also criticised the Security Council and proposed its restructuring. He said:

The Security Council has not argued that the situation in Libya and Côte d'lvoire constituted a threat to international peace and security, because they didn't. Yet they authorise the use of military force. The UN needs to be restructured in a way that it is representative of the people of the world. In the current situation, I doubt if some of the members on the Security Council with veto powers are interested to effect structural change which is urgent. They are contemptuous people and are certainly not in the mood in which they can entertain an African view about the fundamental restructuring of the UN.

Although the matter of Côte d'Ivoire was going to be resolved amicably, unnecessary force was used to produce a particular outcome which has created more problems for the Ivoirians.

Judging from a legal perspective, one can establish a close relationship between the Charter of the UN and the constitution of a state. Just like there is a constitution governing the state, the UN Charter is a constitution governing the international community. Such a constitution must be guided by the principles of equality of all its members as stated in Article 2(1) of the Charter. It should act with fairness and respect in the light of state sovereignty. It should have no class distinctions and all members should enjoy equal privileges. This idea can be compared to that of Karl Marx. According to the Marxist theory of class struggle, (Karl Max theory of Class Consciousness, (online)) where the community is divided into an upper and lower class, there will be a revolution. This means, if the members of the lower class are not well treated, they will rise against the upper class and if precautions are not taken, such a revolution will lead to conflict. Weber considered such revolution a product of capitalism. It applies not only to the state as a body, but also to the international community as well.

The situation that befell Darfur in 2003 is a practical example of what Weber defines as capitalism. From a comparative perspective, opinions put forth by legal activists from the international community suggest that a group of people in the Darfur region of the Sudan are being suppressed by the Sudanese Government. The situation in Darfur has been described by the former UN Secretary-General, Kofi Annan, as "ethnic cleansing;" by President George W. Bush as "an atrocity;" and by Mukesh Kapila, UN Humanitarian Coordinator for Sudan, as "the world's greatest humanitarian crisis in the $21^{\text {st }}$ century" (Gamal, 2008. p.160). It is a tragedy that the Sudanese state has attempted to transform Sudanese society into a "pure" Arab society, whose population should only be composed of those who trace their origins to core Arab countries particularly Saudi Arabia (Gamal, 2008). 
In addition to the views expressed above, the former US Secretary of State, Collin Powell, and the US State Department are of the opinion that the situation in Darfur constitutes genocide (Hassan, 2010. p.20) This determination, however, does not tie with the report of the International Commission of Inquiry on Darfur. The latter suggest that only war crimes and Crimes against Humanity were committed in Darfur, as such they do not meet the criteria of crimes of genocide as prescribed in Article 2 of the Genocide Convention (Reeves E, 2005. para.513). On their part, the UN Security Council adopted resolution 1593 to refer the Darfur situation to the ICC for further clarifications regarding the violation of human rights perpetrated in the region (UN Security Council Resolution 1593, 2005).

Judging from the above literature, one can conclude that the responsibility to protect and to provide humanitarian assistance has not been invoked in Darfur. Kofi Annan underscored the need for all states to embrace such a principle as the basis for collective action against genocide, war crimes, ethnic cleansing and crimes against humanity (Evans, (online). p.707). The UN General Assembly widely acknowledges the importance of the 'responsibility to protect' as a state obligation (Head of States Agreement, 2005. para.139). It emphasizes that the individual state bears the primary responsibility to protect its populations from serious human rights violations that could possibly result in any of the crimes mentioned above. However, when the state fails to protect its populations, the international community may assume such a responsibility. Nonetheless, in relation to Darfur, it is evident that the responsibility to protect and to provide humanitarian assistance has not been invoked.

In reference to the African Union, The Constitutive Act of the African Union (AUCA) provides that the Union shall function with the right to intervene in a Member State pursuant to a decision of the Assembly in respect of grave circumstances, namely war crimes, genocide and crimes against humanity (Constitutive Act of the African Union, 2001. para.4(h)). The UN Security Council resolution 1674 also reiterates the provisions of paragraph 139 of the 2005 World Outcome Document which mandates the international community, through the United Nations, to use appropriate diplomatic, humanitarian and other peaceful means, in accordance with Chapters VI and VIII of the UN Charter, to help protect populations from genocide, war crimes, ethnic cleansing and crimes against humanity (UN Security Council Resolution 1674, 2006).

Although the provisions quoted above provide the basis for which the international community may take actions against Sudan, the UN being the supreme body charged with this responsibility has not been able to reverse the situation in Darfur. Tolstoy focused on the UN Security Council and argues that, to sail into the future is even more than to sail the ocean. There is nothing there. The future will be what people-men, women, children and circumstances make it to be (Tolstoy, 1973. p.1).

\section{Conclusion}

The Darfur crisis may camouflage other motives which have made it a protracted conflict and the efforts of the Security Council and the African Union less successful. Judging from the foregoing, one can conclude that the Council has not been able to reverse the Darfur situation due to lack of proper targeting mechanisms and wrong policy implementations that subsequently leads to a failed diplomacy. So far, the Councils' operations in the region are not justified by the urgent need to resolve the conflict. Rather, they are based on grounds of nepotism, inequality and self interest as revealed in the voting paten observed in previously adopted resolutions. The vision we must present for a future United Nations should not be one filled with vague actions that provide an opportunity for those states that seek to interfere in the domestic affairs of other states. The adoption of Security Council Resolutions must be subject to thorough scrutiny in order to test the true motives of their proponents.

The presence of the veto power rhetoric has also become more of a liability than an asset to the UN Security Council. Particularly, the voting paten witnessed in previous resolutions adopted by the Council reveals that, the permanent members conferred with 'veto' have been acting in a manner that undermines the Councils' authority. There is an urgent need therefore to decentralised the veto power among the fifteen members of the Council or cast it out of existence. This calls for restructuring of the Security Council to compliment the plight of UN member states especially those in Africa whose voices are almost absent in the decision making processes.

\section{References}

Aljazeera.Net, 6 May (2006). "Main points of the deal" available at http://english.aljazeera.net/NR/exeres/685364B5-AF39-47C0-A479031FB50C5C63.htm. (Accessed July 03, 2013)

Annette L. (2012). Khartoum's Pattern of Neglect Continues in Eastern Sudan as Government Expels Aid Group. Available at http://enoughproject.org/blogs/Khartoum-pattern-neglect-continues-eastern-sudan-government-expels-aid-groups. (Accessed 
March 10, 2013)

BBC News, 23 February (2010). "Will Peace return to Darfur". Available at http://news.bbc.co.uk/2/hi/africa/8659037.stm. (Accessed June 14, 2013)

BBC News, 4 May (2010). "Jem Darfur rebels snub Sudan peace talks over 'attacks". Available at http://news.bbc.co.uk/2/hi/africa 18659037.stm. (Accessed December 05, 2012)

Cedric G. (2011). South Sudan: A Difficult Birth. The Washington Post, Washington D.C.

Charter of the United Nations and Statute of the International Court of Justice. Department of Public Information United Nations. New York 10017.

Colum L. (2009). Sudan's 'Coordinated' Genocide in Darfur is Over, U.S. Envoy Says. Washington D.C. Available at http://www.washingtonpost.com/wp-dyn/content/article/2009/06/17/AR2009061703491.html (Accessed December 15, 2012)

Constitutive Act of the African Union: Adopted in 2000 at the Lome Summit (Togo), entered into force in 2001.

Darfur Population as of 2013 Census. Available at http://exploredia.com/darfur-population-2013. Accessed (November 03, 2013)

Donovan P. (2005). The nature of the Conflict in Sudan: A brief overview of the causes and conduct of conflict in Sudan. Peace and Governance Series No. 9, Occasional Paper No. 75. Africa institute of South Africa.

Evans G. From Humanitarian Intervention to Responsibility to Protect. p.707 Available at http://www.fh-muester.de/humanitaerehilfe/downloads/Evans_-_Responsibility_To_Protect.pdf. Accessed 03/12/2013.

Gamal A. (2008). Why has Darfur's Indigenous Population Been Put at Risk?, Peace Review: A Journal of Social Justice. Routledge Publishers London, UK. p.160

Hassan A. (2010). Dimensions of the Darfur crisis and its consequences: An Arab perspective. African Security Review Journal. Volume 19, No.1. Routledge Taylor and Francis Group South Africa.

Head of States Agreement. The Outcome Document of the High Level plenary meeting, (2005). Available at http://www.responsibilitytoprotect.org. (Accessed November 28, 2012)

Karl Marx, The Marxist theory of Class Consciousness. Available at http://www.marxist.org/reference/subject/philosophy Iwork/en/slaughte.htm. (Accessed June 03, 2013)

Kessler et al. (2006). "Sudan Main Rebel Group Sign Peace Deal". The Washington Post, Washington DC.

Omer Y. (2008). The Darfur Situation and the International Criminal Court: An Appraisal. Journal of Politics and Law. Vol.1, No.3.

Rebecca H. (2010). Conflict Displaced Peoples and Refugees. The Washington Post, Washington DC.

Reeves E, (2005). Report of the International Commission of Inquiry in Darfur to the UN Secretary-General, ICID report. IDEA Publishers, New York.

Report of the International Commission on Intervention and State Sovereignty: The Responsibility to Protect. (2001). The International Development Research Centre, Ottawa.

Robert O. (2006). Genocide in Darfur: Investigating the atrocities in Sudan. Routledge Taylor and Francis Group New York.

Statement by Security Council representatives, explanatory notes, Security Council Resolution 1593 of 31/03/2005, Press Release: SC/8351. United Nations, New York.

Statement by Security Council Representatives, explanatory notes, Security Council Resolution 1769 of 31/07/2007, Doc: SC/9089. United Nations, New York.

Sudan Tribune. (2010). African Union undermined Darfur Peace Process-rebels. Available at http://www.sudantribune.com/spip.php ?article34991. (Accessed June 03, 2013)

Sudan Tribune. (2011). Sudan and the LJM rebels Sign a Darfur Peace agreement in Doha. Available at http://www.sudantribune.com ISudan-and-LJM-rebels-sign-a-Darfur,39539. (Accessed June 03, 2013)

Sudan Tribune. (2012). UN-AU peacekeepers attacked in Darfur, 4 wounded. Available at http://www.sudantribune.com/UN-AUpeacekeepers-attacked-in,42353. (Accessed June 03, 2013)

Sunday Times, July 31 ${ }^{\text {st }} 2011$, Pretoria, South Africa.

Tolstoy L. (1973). The Security Council: A Study in Adolescence: Macmillan Publishers New York.

United Nation Security Council Resolution 1556 of 30/07/2004, Press Release: SC/8160. United Nations, New York.

United Nation Security Council Resolution 1564 of 18/09/2004, Press Release: SC/8191. United Nations, New York.

United Nation Security Council Resolution 1590 of 24/03/2005, Press Release: SC/8343. United Nations, New York.

United Nation Security Council Resolution 1591 of 29 March 2005. Doc. S/RES/1591/(2005). United Nations, New York.

United Nation Security Council Resolution 1593 of 31/03/2005, Press Release: SC/8351. United Nations, New York.

United Nation Security Council Resolution 1672 of 25/04/2006, Press Release: SC/8700. United Nations, New York.

United Nation Security Council Resolution 1679 of 16/05/2006, Press Release: SC/8721. United Nations, New York.

United Nation Security Council Resolution 1706 of 31/08/2006, Press Release: SC/8831. United Nations, New York, 2006.

United Nation Security Council Resolution 1755 of 30/04/2007, Press Release: SC/9008. United Nations, New York, 2007.

United Nation Security Council Resolution 1769 of 31/07/2007, Press Release: SC/9089. United Nations, New York, 2007.

United Nation Security Council Resolution 1841 of 15/10/2008, Press Release: SC/9474. United Nations, New York, 2008.

United Nation Security Council Resolution 1935 of 30/07/2010, Doc: SC/9997. United Nations, New York, 2010.

United Nation Security Council Resolution 2035 of 17/02/2012, Doc: S/RES/2035/(2012). United Nations, New York, 2012.

Zygar M. (2004). Behind the UN Security Council Resolution: Chinese, Russia and India Oil Interest in the Sudan. Available at http://www.globalresearch.ca/index.php?contex=va\&aid=612. (Accessed December 05, 2012) 